\title{
Dramatic methanol induced toxic optic neuropathy and dramatically response to erythropoietin: a case report
}

\author{
Majid Shams ${ }^{1}$, Seyed Mohammad Salar Zaheryany ${ }^{2}$ and Reza Bidaki ${ }^{3 *}$ \\ ${ }^{1}$ Assistant Professor of Ophtalmology, Rafsanjan University of Medical Sciences, Rafsanjan, Iran \\ ${ }^{2}$ Medical Student, Iran University of Medical Sciences, Tehran, Iran \\ ${ }^{3}$ Research Center of Addiction and Behavioral Sciences, Shahid Sadoughi University of Medical Sciences, Yazd, Iran
}

\begin{abstract}
Background: To identify the visual outcome of intravenous erythropoietin administration in a patient with Methanol toxic optic neuropathy.

Methods: A patient with methanol toxicity was admitted in ophthalmology service. He had nausea and ophthalmologic symptoms only. Intravenous (IV) injections of 10,000 IU of recombinant human erythropoietin in three successive days were prescribed him.
\end{abstract}

Results: First day, there wasn't any change in examination. But $3^{\text {rd }}$ day, there was significant change in visual acuity. About Right eye $20 / 200$ and Left eye $20 / 400$ and after 3 months, Right eye 20/20 and Left eye 20/40. After six months, the conclusion was the same. Mean while he didn't prescribed no additional drug.

Conclusion: Intravenous erythropoietin may be an effective and safe treatment for patient with methanol toxic neuropathy.

\section{Introduction}

Recent studies have shown that erythropoietin is a cytokine that prevent injury-related tissue damage with non-haematopoietic receptor and keep optimal tissue oxygenation in mammals [1,2]. In addition, we know that Hypoxia may cause elevation of erythropoietin level to 50fold of normal serum concentration [1,2]. Erythropoietin can decline reactive inflammatory reactions [1] that it is proposed to be a secondary impact of decreased apoptosis and explained how erythropoietin, reduces tissue destruction [3]. On the other hand, erythropoietin can act synergistically with VEGF to stimulate angiogenesis at post injury accidents [4]. VEGF can promote and keep vascular integrity by antagonizing inflammation and the leakiness of the endothelial barrier that is promoted by VEGF [5].

Another study indicates that erythropoietin preserves normal vascular auto regulation and prevents spreading injury and vasospasm that can happened because of a micro infarction. The erythropoietin can cause vascular constriction through end erythropoietin that reverse the vascular spasm that accompanies subarachnoid haemorrhage [6].

Recent reviews have shown that erythropoietin can present as a tissue-protective Factor [7-10].

In a Chinese study, the effects of erythropoietin on apoptosis and neuronal proliferation in neonatal rats after infection induced brain damage was investigated and it was recognized that erythropoietin can induce hippocampus neuronal proliferation and decline neuronal apoptosis [11].

\section{Case presentation}

The patient was a 26 years-old single man, that presented by sudden decrease in visual acuity. He noted drinking a drop of Alcohol 2 days ago. He was referred due to poor light perception (OU). He had no previous history of ophthalmologic problems. Family history was negative, too. We didn't find any primary or secondary gain. Therefore, the psychiatric disorders like Conversion disorder and Malingering were ruled out. In his ophthalmologic examination, edemas of optic disc bilaterally were found. Methanol serum level was more than laboratory sensitivity. Hemodialysis was not started for the patient. Erythropoietin with impression of methanol-induced optic neuropathy with dose of 10,000 units IV started twice a day. Intra Ocular pressure, before and after treatment was normal. There was no change in his ophthalmologic examination in the first day after treatment .But at the $3^{\text {rd }}$ day, a significant improve in his visual acuity was developed. His visual acuity was 20/200 for right eye and 20/400 for left eye and after 3 months, it improved to 20/20 for right eye and 20/40 for left eye. He had his routine follow ups for 6 months and no other drug other than erythropoietin was administered and no side effects can be attributed to erythropoietin was reported.

\section{Discussion}

Methanol-induced optic neuropathy is an important and vital status. It causes a special status, both psychologically and medically. Therefore, a favorable intervention, in order to neuroprotection can milden such a crisis for both patient and his/her family significantly. As previous treatments like methyl prednisolone pulse therapy was not

Correspondence to: Bidaki R, Research Centers of Addiction and Behavioral Sciences, Shahid Sadoughi University of Medical Sciences, Yazd, Iran, Tel: 98 3532633555; Fax: (+98) 3532633555; E-mail: Reza_Bidaki@yahoo.com

Key words: erythropoietin, optic neuropathy, methanol

Received: March 10, 2015; Accepted: April 07, 2015; Published: April 10, 2015 
so effective in toxic optic neuropathy, such a treatment that seems to be both effective and safe is of lots of interest.

Response to treatment was rapid and dramatically. We suggest that erythropoietin might be a safe and effective treatment for methanolinduced neuropathy.

It has established that erythropoietin can limit the spread of damage produced by diverse pathologies. Therefore, It may have therapeutic benefits by avoiding adverse effects [12].

In the article by Falavarjani and Modarres, it was been suggested that Erythropoietin can be used as a novel treatment for ocular diseases like vascular occlusions, retinal degenerative disorders and Glucoma [13]. Therefore, it would be logic for evaluation of effect of erythropoietin in other ophthalmologic conditions.

In the case study of Pakravan and Sanjari [14], it was been shown that intravenous erythropoietin may be an effective agent when combined with routine treatments like methyl prednisolone, Folic acid, Vit $B_{6}$ and Vit $B_{12}$ for patients with methanol optic neuropathy [14]. But this case report considered erythropoietin as the only administered treatment.

It is necessary to design RCTs with sufficient cases for further evaluation of efficacy and neuroprotection of the drug.

\section{Conclusion}

Intravenous erythropoietin may be an effective and safe therapeutic intervention for patients with methanol toxic neuropathy and considered as a neuroprotective factor. More surveys are required for assessing the potential benefits of erythropoietin in different optic conditions.

\section{References}

1. Miyake T, Kung CK, Goldwasser E (1977) Purification of human erythropoietin. J Bio Chem 252: 5558-5564. [Crossref]
2. Brines M, Cerami A (2005) Emerging biological roles for erythropoietin in the nervous system. Nat Rev Neurosci 6: 484-494. [Crossref]

3. Gorio A, Gokmen N, Erbayraktar S, Yilmaz O, Madaschi L, et al. (2002) Recombinant human erythropoietin counteracts secondary injury and markedly enhances neurological recovery from experimental spinal cord trauma. Proc Natl Acad Sci USA 99: 94509455. [Crossref]

4. Wang L, Zhang Z, Wang Y, Zhang R, Chopp M (2004) Treatment of stroke with erythropoietin enhances neurogenesis and angiogenesis and improves neurological function in rats. Stroke 35: 1732-1737. [Crossref]

5. Martínez-Estrada OM, Rodríguez-Millán E, González-De Vicente E, Reina M, Vilaró S, et al. (2003) Erythropoietin protects the in vitro blood-brain barrier against VEGFinduced permeability. Eur J Neurosci 18: 2538-2544. [Crossref]

6. Grasso G, Buemi M, Alafaci C, Sfacteria A, Passalacqua M, et al. (2002) Beneficial effects of systemic administration of recombinant human erythropoietin in rabbits subjected to subarachnoid hemorrhage. Proc Natl Acad Sci USA 99: 5627-5631. [Crossref]

7. Dame C, Juul SE, Christensen RD (2001) The biology of erythropoietin in the central nervous system and its neurotrophic and neuroprotective potential. Biol Neonate 79 : 228-235. [Crossref]

8. Juul S (2004) Recombinant erythropoietin as a neuroprotective treatment: in vitro and in vivo models. Clin Perinatol 31: 129-142. [Crossref]

9. Gassmann M, Heinicke K, Soliz J, Ogunshola OO (2003) Non-erythroid functions of erythropoietin. Adv Exp Med Biol 543: 323-330. [Crossref]

10. Ghezzi P, Brines M (2004) Erythropoietin as an antiapoptotic, tissue-protective cytokine. Cell Death Differ 11 Suppl 1: S37-S44. [Crossref]

11. Xu FL, Guo JJ, Zhuang FL, Zhang YH, Wang CH, et al. (2014) Effects of erythropoietin on neuronal proliferation and apoptosis in neonatal rats after infection-induced brain injury. Zhongguo Dang Dai Er Ke Za Zhi 16: 290-294. [Crossref]

12. Brines M, Cerami A (2008) Erythropoietin-mediated tissue protection: reducing collateral damage from the primary injury response. J Intern Med 264: 405-432. [Crossref]

13. Falavarjani KG, Modarres M (2011) Erythropoietin; a novel neuroprotective agent for ocular disorders. J Ophthalmic Vis Res 6: 76-77. [Crossref]

14. Pakravan M, Sanjari N (2012) Erythropoietin treatment for methanol optic neuropathy. J Neuroophthalmol 32: 325-328. [Crossref]

Copyright: (C2015 Shams M. This is an open-access article distributed under the terms of the Creative Commons Attribution License, which permits unrestricted use, distribution, and reproduction in any medium, provided the original author and source are credited. 